628.14(497.5Dubrovnik)"14"

Primljeno: 24. 5. 2019.

Prihvaćeno: 17. 6. 2019.

Izvorni znanstveni rad

DOI: $10.22586 /$ pp.v56i1.8405

Irena Ipšić
Ivana Lazarević ${ }^{* *}$

\title{
Water in the urban space of Dubrovnik ${ }^{1}$
}

\author{
Another to health very beneficial principle is a plentitude of fresh water, \\ without which a well- organised city cannot be. \\ Philippus de Diversis
}

\begin{abstract}
Many city wells and public cisterns, along with the water supply system built from the spring in Šmet to the urban centre in the fifteenth century, are an eloquent testimony of the great concern of the Dubrovnik authorities to provide its inhabitants with a sufficient and regular supply of fresh water. The mapping of public water locations inside the walled city area indicates the elite urban parts inhabited by the bulk of the nobility. Prior to the construction of the aqueduct, it was the area of Bunićeva poljana, today's Ulica od puča, in which the majority of wells had been dug. After the construction of the aqueduct, and in conformity with new communal solutions, the elite part shifted northwards, around the Placa, main street, which transformed into a new city centre.
\end{abstract}

Key words: Dubrovnik, water, Onofrio della Cava, aqueduct, wells, cisterns

\section{Water in the city before the aqueduct}

The quality of life and socio-economic development of a certain area rely most directly on the access to fresh water resources and the government attitude towards

\footnotetext{
* Irena Ipšić, History of the Adriatic and the Mediterranean, University of Dubrovnik, Branitelja Dubrovnika 41, 20000 Dubrovnik, Croatia,E-mail: irenaipsic@gmail.com

** Ivana Lazarević, The Institute for Historical Sciences in Dubrovnik, Croatian Academy of Sciences and Arts, Lapadska obala 6, 20000 Dubrovnik, Croatia, E-mail: ivana.lazarevic@du.t-com.hr

1 This research was conducted within the framework of the project URBES funded by the Croatian Science Foundation under no. IP-2014-09-7235.
} 
water supply. ${ }^{2}$ Dubrovnik area is extremely rich in water resources, and apart from the Ombla River, as the most ample resource of fresh water, there are a number of natural springs and streams important for the water supply of the Dubrovnik region, such as smaller rivers Ljuta, Smokovjenac or the aquaclamada Spilen in Plat, or Bota in Čajkovici, for example. ${ }^{3}$ From the very beginnings, water supply in the city itself did not rely on one source only or the collection of rainwater, but also on numerous wells (pučevi). Most of them were located in the Ulica Od puča (as many as 16 are mentioned), after which the street was named. Arhaeological excavation has confirmed the location of two wells from late antiquity at Bunićeva poljana, and one underneath the Cathedral. ${ }^{4}$ Wells were also built in the earliest period of the city history beneath the church of St Saviour, in the immediate vicinity of Onofrio's Great Fountain, in the convent of St Clare, in the upper cloister of the Franciscan monastery, in Miho Pracat Street, as well as in the house next to the Cathedral (Map 1). ${ }^{5}$

2 On the territory of Eastern Adriatic coast water supply systems have been built since the antiquity, such as those in Pula, Omišalj on the island of Krk, Rab, Zadar, Novalja and the island of Pag, Diocletian's Palace in Split and in Cavtat. Cf. Mate Suić, Antički grad na istočnom Jadranu [Ancient cities in the Eastern Adriatic] (Zagreb: Golden marketing, 2003), 192; Nikola Crnković, "Novaljska župna kronika o jedinstvenom vodoopskrbnom objektu na našem tlu" [The parish chronicle of Novalja on the unique water supply facilities in our country], Croatica Christiana periodica 9 (1985), no. 15: 89-101; Joško Belamarić, Dioklecijanov akvedukt [Diocletian's aqueduct] (Split: Ministarstvo kulture Republike Hrvatske, Uprava za zaštitu kulturne baštine, Konzervatorski odjel, 1999); Radoslav Bužančić, "Fontana Dioklecijanove carske palače" [The cistern in Diocletian's imperial palace], Klesarstvo i graditeljstvo 1-2 (2009), no. 20: 54-65; Katja Marasović, Snježana Perojević, Jure Margeta, Miroslav Katić, Davor Bojanić, “Istraživanje salonitanskog akvedukta 2014.-2015." [Research on the Salonitan aqueduct (2014-2015)], Vjesnik za arheologiju i povijest Dalmatinsku 109 (2016): 129-154; Katja Marasović, Jure Margeta, "Istraživanje antičkih vodnih zahvata na izvoru rijeke Jadro / A Study of Roman Water Intake Structures at the Jadro River's Spring", Vjesnik za arheologiju i historiju dalmatinsku 110 (2017), no. 2: 509-532. Dubrovnik area witnessed the construction of the ancient Vodovada-Cavtat aqueduct, which delivered water to Epidaurus, a Roman colony at the time. Cf. Ljiljana Kovačić, "Antički vodovod - Vodovađa" [The ancient water supply system of Vodovađa], Zbornik dubrovačkih muzeja (2004): 331-340.

3 For more details on natural water resources and hydronyms on the territory of the Ragusan Astarea see: Josip Lučić, Prošlost dubrovačke Astareje: Župe, Šumeta, Rijeke, Zatona, Gruža i okolice grada do 1366 [A history of Dubrovnik's Astarea: Župa, Šume, Rijeka, Zaton, Gruž, and the surroundings of the city before 1366] (Dubrovnik: Matica hrvatska, 1970), 11-24.

4 The oldest well at Bunićeva poljana, that next to the eastern layer of the former defence wall, was obviously abandoned, because in the early Middle Ages two graves were built above it by the four-leafed memoria. Cf. Josip Stošić, "Prikaz nalaza ispod katedrale i Bunićeve poljane u Dubrovniku" [Presentation of the finds under the cathedral and Bunićeva Poljana in Dubrovnik], Arheološka istraživanja u Dubrovniku i dubrovačkom području 12 (1988): 16; Antun Ničetić, Povijest dubrovačke luke [A history of Dubrovnik's harbour] (Dubrovnik: Zavod za povijesne znanosti HAZU u Dubrovniku, 1996), 23-24; idem, Nove spoznaje o postanku Dubrovnika, o njegovu brodarstvu i plovidbi svetog Pavla [New insights about the emergence of Dubrovnik, its shipping, and the navigation of St Paul] (Dubrovnik: Sveučilište u Dubrovniku, 2005), 95-103.

5 Vladimir Bazala, Pregled povijesti zdravstvene kulture Dubrovačke Republike [An overview of healthcare in the Dubrovnik Republic] (Zagreb: Dubrovački horizonti, 1972), 16-17; Ničetić, Povijest dubrovačke luke, 23-24; Ničetić, Nove spoznaje o postanku Dubrovnika, 95-103; Relja Seferović, Mara Stojan, "Čudo vode: prolegomena za ranorenesansni vodovod u Dubrovniku" [The miracle of water: Prolegomena to the Renaissance water supply system in Dubrovnik], Anali Zavoda za povijesne znanosti HAZU u Dubrovniku 44 (2006): 98. 
Map 1. Wells (zdenci) and public cisterns in Dubrovnik before the construction of the aqueduct

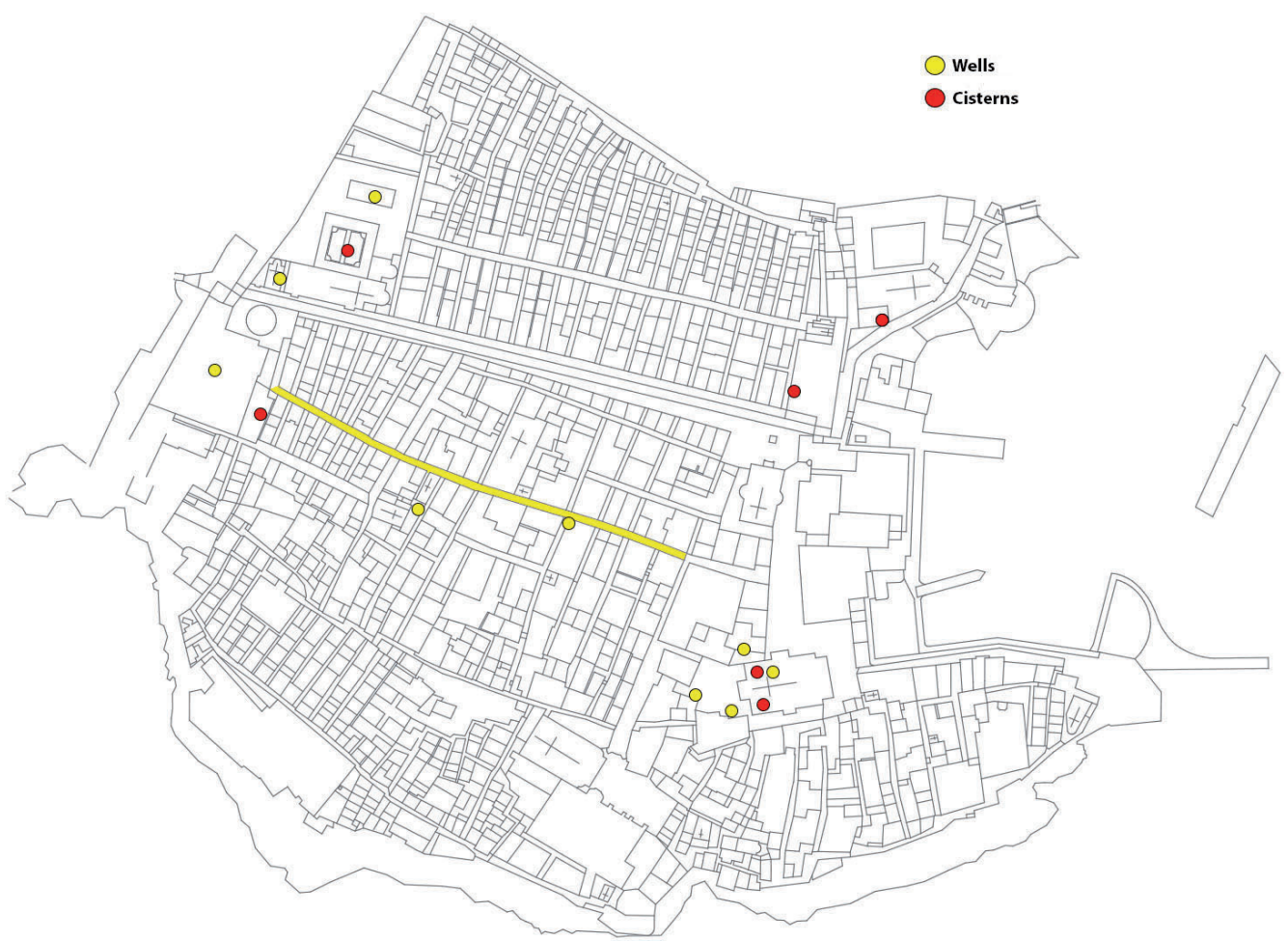

Besides wells, the city population also used water from the public and private cisterns (gustijerne) in which rainwater from the roofs was collected. The majority of public cisterns was built in the fourteenth century (Map 2). In 1304 probably the first public cistern was constructed on the site of today's west wing front of the Sponza Palace (Customs House). ${ }^{6}$ In the late fourteenth century, between 1388 and 1389, two state cisterns were built: one near the Franciscan, and the other by the Dominican monastery. ${ }^{7}$ Between 1389 and 1391 Nikola Marinov Menze ${ }^{8}$ built

\footnotetext{
6 Risto Jeremić, Jorjo Tadić, Prilozi za istoriju zdravstvene kulture starog Dubrovnika [Contributions to the history of healthcare in historical Dubrovnik], vol. I (Begrade: Biblioteka Centralnog higijenskog zavoda, 1938), 37; Lukša Beritić, "Dubrovački vodovod" [Dubrovnik’s water supply system], Anali Historijskog instituta JAZU u Dubrovniku 8-9 (1960-1961): 99.

7 Croatia (forth: HR) - State Archives in Dubrovnik (forth: DADU) - fond 1. Reformationes (forth: Ref.), vol. 28, f. 3v, 33-33v, 77; HR-DADU-460. Family Beritić (forth: Fond Beritić), box. 10, notes 110, f. 12, 14; Beritić, "Dubrovački vodovod", 99-100.

8 Nikola Marinov Menze, nicknamed 'Preslica' (c. 1325-1402), was an ambassador and surveyor of the great Ragusan construction projects. He held various Republic offices, such as judge, member of the Minor Council and rector in 13 mandates. HR-DADU-12.1. Testamenta Notariae (forth: TN), vol. 9, f. 1-3v; Nenad Vekarić, Vlastela grada Dubrovnika, vol. 5. Odabrane biografije (E-Pe) [Dubrovnik's nobility, vol. 5: Selected biographies (E-Pe)] (Zagreb; Dubrovnik: Zavod za povijesne znanosti HAZU u Dubrovniku, 2014), 232; Nenad Vekarić, Vlastela grada Dubrovnika, vol. 8. Genalogije (M-Z) [Dubrovnik's nobility,
} 
a large cistern next to the eastern wall of the convent of St Clare. The cistern was around 7 metres deep, and collected rainwater from the convent roofs through a conduit 33 metres long. Apparently, this water was the coldest in the city. ${ }^{9}$ Mentioned in a couple of documents from the fourteenth and fifteenth century are two cisterns underneath the Cathedral. ${ }^{10}$

Map 2. Fountains and cisterns to the nineteenth century

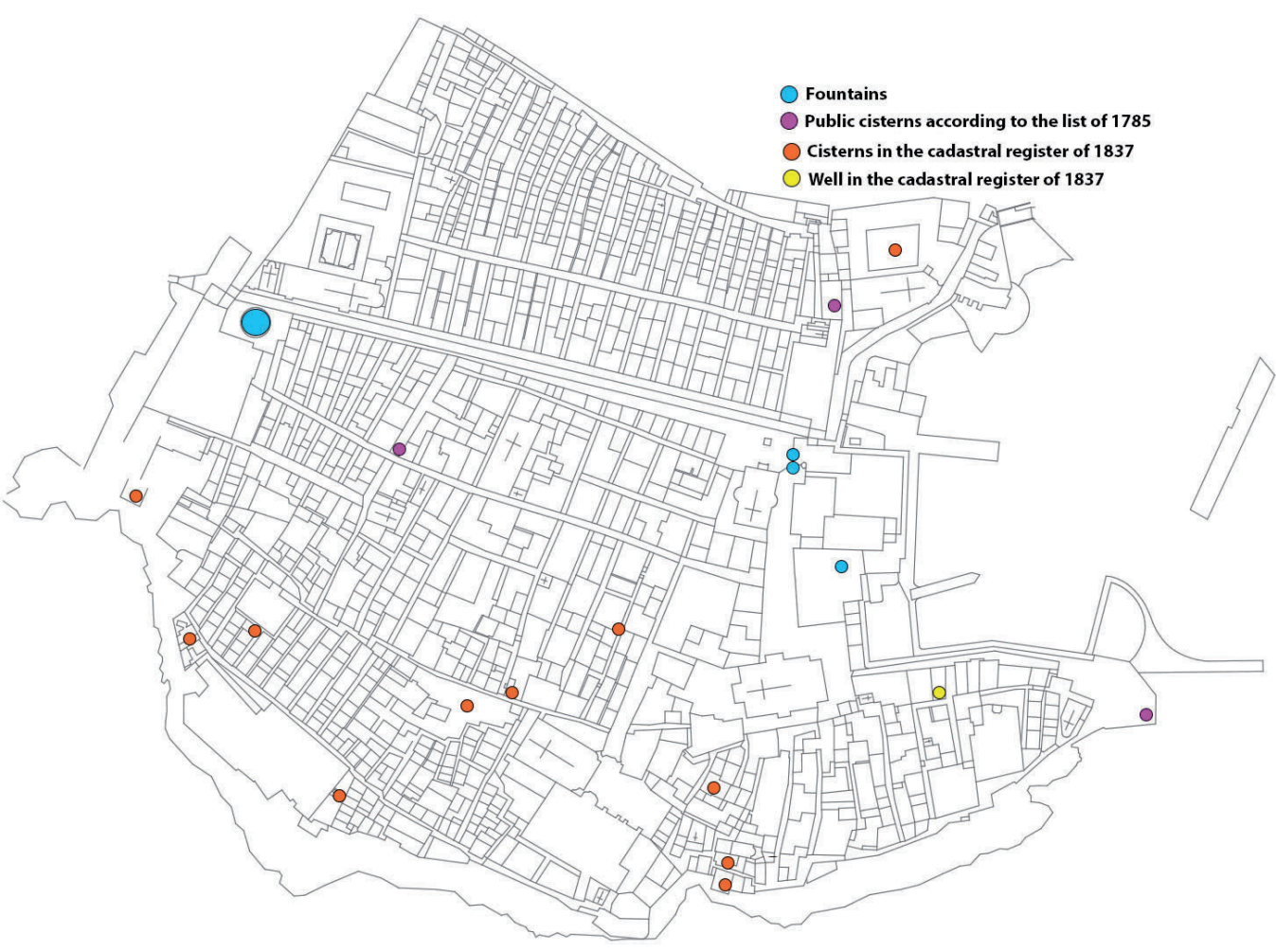

vol. 8: Geenealogies (M-Z)] (Zagreb; Dubrovnik: Zavod za povijesne znanosti HAZU u Dubrovniku, 2017), 44.

9 Ref. vol. 29, f. 13v, 41v. Fond Beritić, box 10, notes. 110, f. 19-20. The cistern at St Clare's convent still exists, though in 1919 it fell into disuse (Beritić, "Dubrovački vodovod", 100). For more details on this cistern see: Jeremić, Tadić, Prilozi za istoriju zdravstvene kulture starog Dubrovnika, vol. I, 37; Krasanka Majer Jurišić, Edita Šurina, Velika Onofrijeva fontana u Dubrovniku - povijesnoumjetnička i konzervatorska studija [Onofrio's large cistern in Dubrovnik: An art-historical and conservationist study] (Zagreb: Ministarstvo kulture, Uprava za zaštitu kulturne baštine, 2016), 10-11.

${ }^{10}$ In 1367 it was decided that one cistern be placed at the disposal of the archbishop, and in 1411 to have them both repaired for tanking fresh water. In 1492 north cistern in the Cathedral was placed at the disposal of the local dwellers, on condition that the water from it could not be used for laundry. Danko Zelić, "Arhitektura starih katedrala" [Architecture of historical cathedrals], in: Katedrala Gospe Velike u Dubrovniku, ed. Katarina Horvat Levaj (Dubrovnik; Zagreb: Gradska župa Gospe Velike and Institut za povijest umjetnosti, 2014), 45, 63 (note 61). 
Due to long dry seasons in the summer months, Dubrovnik public cisterns ( $g u$ stijerne) often ran dry, while the water from the wells turned too salty. For this reason extra supplies of fresh water were transported to the city by ships from the spring in Mlini. ${ }^{11}$ In the earlier periods, one ship a day sufficed, while from the fifteenth century on not even three ships carrying water could meet the city's water demands. In October 1434, as many as ten ships carried water from the spring in Mlini to the city. Water was sold in the city port, yet it soon became quite clear that this solution could not meet the city's water demands in the longterm perspective. ${ }^{12}$

\section{Aqueduct}

The problem of water shortage intensified with the growth of the city population at the dawn of the fifteenth century (according to the estimate of Stjepan Krivošić, the city had around 3,500 inhabitants at the end of the $14 \mathrm{c}$. and 6,000 at the end of the $15 \mathrm{c}$.), ${ }^{13}$ but also with the development of crafts and industry, ${ }^{14}$ as well as the

\footnotetext{
${ }^{11}$ Beritić, "Dubrovački vodovod", 99.

${ }^{12}$ Jeremić, Tadić, Prilozi za istoriju zdravstvene kulture starog Dubrovnika, vol. I, 38; Seferović, Stojan, "Čudo vode", 99. Other cities faced a similar problem of water supply. In Venice, for example, water supply was hampered by the very location of the city. As the wells and cisterns lay in shallow ground, they were susceptible to the weather conditions, such as drought, but also heavy rain seasons, during which seawater penetrated the wells and tanks. Venice, too, tried to solve the problem of water supply by carrying water from the Brenta by ships. Cf. Fernand Braudel, Civilization and Capitalism, $15^{\text {th }}-18^{\text {th }}$ Century. Volume 1: The Structures of Everyday Life: The Limits of the Possible, trans. and rev. Sian Reynolds (London; Glasgow; Sydney; Auckland; Toronto; Johannesburg: William Collins Sons \& Co Ltd, 1981), 227-231; Raffaella Sarti, Živjeti u kući: stanovanje, prehrana i odijevanje u novovjekovnoj Europi (1500.-1800.) [Living in a house: Housing, food, and clothing in early modern Europe] (Zagreb: Ibis grafika, 2006), 133. Apart from the problems with water supply, cities had problems with bad hygienic conditions. Stagnant water which was used on a daily basis, was often contaminated with various and animal waste, mud and other impurities from different businesses and workshops. According to medical manual and advices, spring water was the best, provided that it is filtered with sand. The rainwater was also considered healthy because it regulated the digestion. Such water was advised to be boil and filtered with wool fleece before consumption, or to be mixed with vinegar, sour wine, honey or liquorice. Cf. Fabijanec, "Uloga vode u svakodnevnom životu srednjovjekovne Hrvatske", 34).

${ }^{13}$ Stjepan Krivošić, Stanovništvo Dubrovnika i demografske promjene u prošlosti [The population of Dubrovnik and its demographic changes in the past] (Dubrovnik: Zavod za povijesne znanosti JAZU u Dubrovniku, 1990), 18; Nenad Vekarić, Vlastela grada Dubrovnika, vol. 1 - Korijeni, struktura i razvoj dubrovačkog plemstva [Dubrovnik's nobility, vol. 1: The roots, structure, and development of Dubrovnik's nobility] (Zagreb; Dubrovnik: Zavod za povijesne znanosti HAZU u Dubrovniku, 2011), 241.

${ }^{14}$ Cloth manufacture, which began to develop rapidly at the beginning of the fifteenth century, required large quantities of water. Its shortage greatly impacted the regular activity of the textile workshops up until the construction of the aqueduct. Cf. Dragan Roller, "Dubrovački zanati u XV. i XVI. stoljeću" [Crafts in Dubrovnik (15 ${ }^{\text {th }}-16^{\text {th }} \mathrm{c}$.)], in: Grada za gospodarsku povijest Hrvatske, vol. 2, ed. Mijo Mirković (Zagreb: Jugoslavenska akademija znanosti i umjetnosti, 1951), 29-30; Joško Belamarić, "Urbanistički aspekti prve dubrovačke industrije u 15. stoljeću" [Urbanist aspects of Dubrovnik’s earliest industry in the $15^{\text {th }}$ century], in: Zbornik Dana Cvita Fiskovića II - Renesansa i renesanse u umjetnosti Hrvatske, ed. Predrag Marković and Jasenka Gudelj (Zagreb: Institut za povijest umjetnosti, 2008), 341-372; Fabijanec, "Uloga vode u svakodnevnom životu srednjovjekovne Hrvatske", 16; Francesco Bettarini, La
} 
increased housing construction in the walled inner area. ${ }^{15}$ Being an issue of major importance to both the inhabitants and the city economy, ${ }^{16}$ the government began to seek a new solution to the growing water demands of Dubrovnik. The construction of a water supply system proved as the best long-term solution, by which, from a spring in Šumet, water would be delivered to the walled inner city area. Engaged for this project was Onofrio de Giordano della Cava. ${ }^{17}$ Once the entire route of the aqueduct had been completed, the building of the city fountains began. The builders first embarked upon the works on the Great Fountain, which represented the final phase of the aqueduct project, for which Onofrio della Cava was also commissioned..$^{18}$ Several months later, it was decided to build another fountain, Small Fountain, at the other end of the Placa. The contract on the construction of the Small Fountain was signed in October 1440 between Onofrio and the sculptor Peter Martin of Milan on one side and the supervisors of the

comunità pratese di Ragusa (1414-1434). Crisi economicae migrazioni collettive nel Tardo Medioevo (Florence: Olschki, 2012); Francesco Bettarini, "I contratti di assunzione nella manifattura tessile Ragusea", Dubrovik Annals 20 (2016): 53-92.

${ }_{15}$ Population increase and accumulated wealth in the fifteenth and sixteenth centuries contributed to a stronger growth of the city. In compliance with urban regulations, by the start of the century all wooden houses were replaced by those built of stone. Parts of the old walls were pulled down, the construction of the fortresses such as Lovrijenac, Minčeta and Revelin either commenced or was already in progress, the city harbour and Kaše breakwater witnessed certain extensions, the city granary was being built, as well as the belfries, Rector's Palace with the city hall was renovated, the city streets were stone paved and the sewer was also introduced (Roller, Dubrovački zanati u XV. i XVI. stoljeću, 121; Lukša Beritić, Urbanistički razvitak Dubrovnika [The urban development of Dubrovnik] (Zagreb: Zavod za arhitekturu i urbanizam Instituta za likovne umjetnosti JAZU, 1958), 71; Lukša Beritić, Utvrđenja grada Dubrovnika [Dubrovnik's fortifications] (Zagreb: JAZU, 1955), 93, 95; Stjepan Ćosić, Nenad Vekarić, "Dubrovačka Republika" [The Dubrovnik Republic], Hrvatska enciklopedija 3 (2001), 279; Nada Grujić, "Knežev dvor u Dubrovniku prije 1435. godine" [The Rector's Palace in Dubrovnik before 1435], Povijesni prilozi 40 (2005): 149-170; Vekarić, Vlastela grada Dubrovnika, 1, 240-246).

${ }^{16}$ Beritić, "Dubrovački vodovod", 100. The wells (pučevi), which until then had satisified the needs of the inhabitants, were so heavily drained out that the water in them turned brackish. This water (mixed with seawater) was not adequate for drinking, but could be used for bathing, laundry or cooking. In the mentioned conditions, not even the numerous cisterns that collected water from the roofs were able to secure sufficient supply of water, as a result of which the city was faced with a chronic shortage (Seferović, Stojan, "Čudo vode", 98-99).

${ }^{17}$ HR-DADU-2 Consilium Maius, vol. 5, f. 79v-81v (DAD). Transcript of the contract was published by Risto Jeremić, Jorjo Tadić, Prilozi za istoriju zdravstvene kulture starog Dubrovnika [Contributions to the history of healthcare in historical Dubrovnik], vol III (Belgrade: Biblioteka Centralnog higijenskog zavoda, 1940), 11-14. For more on the construction of the Renaissance aqueduct in Dubrovnik see: Beritić, "Dubrovački vodovod", 100; Filip (de) Diversis, Opis slavnoga grada Dubrovnika [A description of the glorious city of Dubrovnik], preface, transcription and translation from Latin by Zdenka Janeković Römer (Zagreb: Dom i svijet, 2004), 59-60; Seferović, Stojan, “Čudo vode”, 101-104.

${ }_{18}$ The contract with Onofrio was signed on 7 February 1438: HR-DADU-15 Diversa Cancellariae (forth: DC), vol. 52, f. 70-72; Jeremić, Tadić, Prilozi za istoriju zdravstvene kulture starog Dubrovnika, vol. III, 15-18; Renata Novak Klemenčič, "Dubrovniška Velika fontana" [Dubrovnik's Large Cistern], Zbornik za umetnosno zgodovino, n.s. 39 (2003): 83-86; Majer Jurišić, Šurina, Velika Onofrijeva fontana u Dubrovniku, 74-75. 
waterwork construction. ${ }^{19}$ As proof that the site for the building of the Great Fountain was carefully chosen is the account of Philippus de Diversis, according to which the Great Fountain was erected next to St Clare's convent, "because that is the largest space" for such a magnificant construction. ${ }^{20}$ This space had already served as a location at which water was disributed, since in the vicinity there used to be a public cistern, built along the eastern wall of St Clare's by Nikola Menze at the end of the fourteenth century. ${ }^{21}$

The construction of an aqueduct with two fountains in the city was a project whose significance marked the future development of Dubrovnik. Once completed, it contributed to the improvement of the living standard in the city in terms of hygienic and sanitary conditions, it helped reduce filth and unplesant odours and, as an essential prerequisite for certain economic activities, notably cloth industry, provided a strong impetus for its development. ${ }^{22}$ Equally, water wihin the walled city area represented a civilisational achievement, not only because of the rise in the living standard and the economic context, but also as an expression of solidarity. ${ }^{23}$ Comunal value of this project can be seen in the fact that the water supply system built at 15th century supplied the city, with some minor changes and modifications, through the middle of the $20^{\text {th }}$ century.

\section{Water after the construction of the aqueduct}

Public spaces with water were seen as the points of gathering and communication, that is, as a major focus of social life and urban everyday life. There, one could feel the city pulse, learn the latest city rumours, negotiate business arrangements or see to one's affairs. ${ }^{24}$ Water became an important architectural design element in the spatial urban structure. Fountains, wells and cisterns adorned the

\footnotetext{
${ }^{19}$ HR-DADU-9 Diversa Notarie, vol. 24 f. 147v. Jeremić, Tadić, Prilozi za istoriju zdravstvene kulture starog Dubrovnika, vol. III, 18-19; Beritić, "Dubrovački vodovod", 101; Seferović, Stojan, "Čudo vode", 123-124.

${ }^{20}$ Diversis, Opis slavnog grada Dubrovnika, 60.

${ }^{21}$ Majer Jurišić, Šurina, Velika Onofrijeva fontana u Dubrovniku, 10-11.

${ }^{22}$ Seferović and Stojan, "Čudo vode", 132-133. For the purposes of the cloth industry, which was mainly situated at the Pile area, a certain amount of water from the aqueduct separated into different canal by the deposit next to the Minčeta fortress.

${ }^{23}$ Zdenka Janeković Römer, "Extension of the Ragusan Aqueduct from the Spring in Knežica, 15181520: Common Concern of the Government and People for the Common Good", in: Scripta in honorem Igor Fisković. Zbornik povodom sedamdesetog rodendana. Festschrift in the occasion of his $70^{\text {th }}$ birthday, ed. Miljenko Jurković and Predrag Marković (Zagreb; Motovun: University of Zagreb, Faculty of Humanities and Social Sciences, International Research Center for Late Antiquity and the Middle Ages, 2015), 325-326.

${ }^{24}$ Lewis Mumford, Grad u historiji. Njegov postanak, njegovo mijenjanje, njegovi izgledi (Zagreb: Naprijed, 1988), 297-298 (originally published in 1961 as The City in History: Its Origins, Its Transformations, and Its Prospects).
} 
public but also private urban spaces. ${ }^{25}$ With this regard, Marin Držić, too, chose Onofrio's fountain as the setting of his Novela od stanca, in which Stanac "prislonio prid fontanu uz mir" ('leaned on the wall by the fountain'). ${ }^{26}$

In the eighteenth century, the Small Fountain also served for laundry purposes, and next to it, built into the pavement, was a small stone container (kamenica) from which animals drank water. In the vicinity was the city loggia, a gathering place of noblemen, foreigners and passers by. In front of the loggia, not far from the Small Fountain, was the city market, so that the proximity of fresh water on this spot was a true blessing, and a place that equally attracted merchants and vendors, housewives and maids. ${ }^{27}$

Similar to rural areas, in the city water fetching was mainly done by women, most commonly by housemaids. The latter were present daily on one of the city fountains, where, regardless of the weather conditions, frost or wind, they fetched water or washed clothes. On their way back from the fountain, they always carried a bucket of water on the head. Fountain was the place where, in jest and song, they exchanged news about their kin back in the village. On occasion, they flirted with the soldati (soldiers), or at times even had to defend themselves from assaulters. For example, on 7 July 1624, Đuro Sikojević found Maruša, maid in the household of Đuro Ghetaldi, washing clothes on the fountain. He grabbed her by the breasts, upon which she hit him with a stone. He responded by punching her on the face. Bystanders Rado Đurov and other soldiers watched the assault calmly. ${ }^{28}$ Maids coming to the fountain were also known to be robbed. Thus Maruša, servant of a certain Roza, was the victim of theft on 26 July 1629, whereby Anukla, maid of Đivo Vlahov, and his wife Kata stole some of her washed clothes. ${ }^{29}$ The Great Fountain was also known to be the scene of most serious crimes. Hence, on 3 March 1642, the judges of the Criminal Court in Dubrovnik received a report on a dead newborn found on the crown of the Great Fountain. The enquiry into

\footnotetext{
${ }^{25}$ Joško Sindik, Maja Briški, "Različitost percepcije simboličkog značenja vode" [Various perceptions of the symbolic meaning of water], Anali Zavoda za povijesne znanosti HAZU u Dubrovniku 54 (2016), no. 2: 456; Mara Marić, Projektno tehnička dokumentacija za obnovu trase dubrovačkog renesansnog vodovoda. Konzervatorski elaborat (predstudija obnove i potrebna ispitivanja) [Project documentation for the renovation of Dubrovnik's historical water supply system: A preliminary conservationist study] (Dubrovnik: Trames Consultants d.o.o., 2015), 11.

${ }^{26}$ Milovan Tatarin, "Onofrijeva fontana” [Onofrio’s cistern], Leksikon Marina Držića (Zagreb: Leksikografski zavod Miroslav Krleža, 2009), 558-559; Cvito Fisković, "Petar Martinov iz Milana i pojava renesanse u Dubrovniku" [Pietro di Martino da Milano and the beginings of the Renaissance in Dubrovnik], Prilozi povijesti umjetnosti u Dalmaciji 27 (1988): 114.

${ }^{27}$ Fisković, "Petar Martinov iz Milana i pojava renesanse u Dubrovniku", 114-119; Slavica Stojan, Vjerenice i nevjernice. Žene u svakodnevici Dubrovnika (1600-1815) [Brides and adulteresses: Women in the everyday life of Dubrovnik (1600-1815)] (Zagreb; Dubrovnik: Zavod za povijesne znanosti HAZU u Dubrovniku, 2003), 121-122.

${ }^{28}$ Stojan, Vjerenice i nevjernice, 121-122.

${ }^{29}$ Ibid., 122.
} 
the establishment of the culprits gave no result, thus leaving those who left the newborn at the Fountain unpunished. ${ }^{30}$

In addition to the Great and Small Fountain, Dubrovnik also had a Jewish Fountain, ${ }^{31}$ a fountain in the Rector's Palace, cisterns in the Franciscan and Dominican monasteries, along with private cisterns in private houses and in the majority of patrician palaces (Map 2). The list of the public cisterns from 1785 (Nota dellepubliche cisterne per li castelli e luoghi publici), kept at the State Archive in Dubrovnik, ${ }^{32}$ includes 14 cisterns, of which one has been destroyed and is not in use, as well as 156 private wells, described as small in capacity (Map 2). ${ }^{33} \mathrm{Un}$ fortunately, the next known source about the cisterns inside city walls dates back to after the fall of the Republic. It is the cadastral register of the construction plots from 1837 which provides record of one well and 11 cisterns, some of which are private property. By the 1876 reambulation, three cisterns had lost their original purpose, and the entry was corrected. ${ }^{34}$ The cisterns which were located (and still are so) on the groundfloors of the housing units were not recorded.

As to how important the main city fountain actually was may be learnt from the names of the sexteria in the so-called French census of 1807, and the population census from 1817. Both censuses include the same systematisation of the sexteria: Minčeta, Dogana, Great Fountain (Fontana grande), Hospital (Ospedale Civile), Saint Mary, Forte Molo (St John Fort). Each sexterium was named after a prominent landmark on its territory. ${ }^{35}$

The Great Fountain (Fontana Grande) sexterium covered the area from the church of St Blaise to the Great Onofrio Fountain. On its northern side, the sexterium bordered the Placa (Stradun), and Ulica od puča on the southern side. According to the 1817 census, this sexterium had the largest number of the members of noble lineages ${ }^{36}$ Each of the grand palaces that belonged to the members of the nobility had its own private cistern (gustijerna). Today, these water tanks are mainly out of

\footnotetext{
${ }^{30}$ Ibidem.

${ }^{31}$ Before the earthquake of 1667, Jewish Fountain was probably located in the ghetto. It was embellished with a lion head, and according to legend, parts of it were relocated to Pile. This fountain is still in use. Cf. Vesna Miović, Židovski geto u Dubrovačkoj Republici (1546-1808) [The Jewish ghetto in the Dubrovnik Republic (1546-1808)] (Zagreb; Dubrovnik: Hrvatska akademija znanosti i umjetnosti, Zavod za povijesne znanosti u Dubrovniku, 2005), 88-89.

${ }^{32}$ HR-DADU-47, Custodiae et armamentum (forth: CA), vol. 84.

${ }^{33}$ HR-DADU-47, CA, vol. 84, Piani si difesa e oservazioni sulle fortificazioni dell' anno 1785, f. 12-12v.

${ }^{34}$ HR-State Archives in Split (forth: DASt), fond 152, Arhiv mapa za Istru i Dalmaciju (forth: AMID), box 145 .

${ }^{35}$ For more on sexteria see: Ivana Lazarević, Vlasteoske kuće u gradu Dubrovniku 1817. godine [Nobile houses in Dubrovnik in 1817] (Zagreb; Dubrovnik: Zavod za povijesne znanosti HAZU u Dubrovniku, 2014), 35-38; eadem, "Granice dubrovačkih seksterija" [The boundaries of Dubrovnik’s sestieri], Anali Zavoda za povijesne znanosti HAZU u Dubrovniku 50 (2012): 63-74.

${ }^{36}$ The census of 1817 is the first preserved population census of the city nucleus by name, and mirrors the state after the fall of the Republic. For more on the census see Lazarević, Vlasteoske kuće u gradu Dubrovniku 1817. godine, passim.
} 
usage, yet the well crowns, often decorated with noble coats of arms, bear witness to their existence. It should be noted that in the cadastral register of the construction plots from 1837 none of the entered public cisterns was in this sexterium, but in the sexteria of St Mary, Hospital and Forte Molo (Map 2).

\section{Position of the wells considering the position of the Dubrovik elites}

Throughout the history of the old city nucleus of Dubrovnik, one may observe certain elements of status disperison and grouping. ${ }^{37}$ The mentioned elements are also likely to be traced in the position of the wells and fountains. For example, the investigation carried out by Nenad Vekarić with an aim to elucidate the events from 1205 in the history of Dubrovnik and the role of the deposed count Damjan Juda shows that the estate of the then first man in Dubrovnik was "in front of the Cathedral door," therefore, at the most elite location of the day. ${ }^{38}$ On this site as many as 3 wells have been discovered (Map 1).This estate was later inherited by Juda's daughter, married Gundula, and then by the granddaughter Bona Gundula, founder of the noble Bona lineage. The estate was located on the area of today's Bunićeva poljana. ${ }^{39}$ Ulica od puča was in 1817 lined with 14 grand patrician palaces, occupied by 30 members of the noble circle. ${ }^{40}$ Those palaces were the main palaces of noble families and they stood by the busiest commercial street. One should bear in mind, however, that in 1817 only 225 members of the nobility (or $4.02 \%$ of the overall population) lived in the city of Dubrovnik. A couple of centuries earlier, for instance, in the fourteenth century, the proportion of the noble rank in the overall population was around $40 \%$, and there is reason

\footnotetext{
${ }^{37}$ The impact of status division of the city society on the urban space has been detected in Dalmatian cities. For more on this point see: Zdenka Janeković-Römer, The Frame of Freedom. The Nobility of Dubrovnik between the Middle Ages and Humanism (Zagreb; Dubrovnik: Zavod za povijesne znanosti HAZU u Dubrovniku, 2015), 338-339; Mladen Andreis, Irena Benyovsky, Ana Plosnić, "Socijalna topografija Trogira u 19. stoljeću" [Social topography of Trogir in the $19^{\text {th }}$ century], Povijesni prilozi 25 (2003): 51; Irena Benyovsky Latin, Srednjovjekovni Trogir: prostor i društvo [Medieval Trogir: Space and society] (Zagreb: Hrvatski institut za povijest, 2009), 129-130. For more on the Dubrovnik example see: Lazarević, Vlasteoske kuće u gradu Dubrovniku 1817. godine, 31-34.

${ }^{38}$ Nenad Vekarić, Nevidljive pukotine. Dubrovački vlasteoski klanovi [Invisible fissures: Ragusan patrician clans] (Zagreb; Dubrovnik: Zavod za povijesne znanosti HAZU u Dubrovniku, 2009), 26-30; Lazarević, Vlasteoske kuće u gradu Dubrovniku 1817. godine, 31, 187-189.

${ }^{39}$ Vekarić, Nevidljive pukotine, 26-30; Lazarević, Vlasteoske kuće u gradu Dubrovniku 1817. godine, 31; Nenad Vekarić, Vlastela grada Dubrovnika, vol. 2. Vlasteoski rodovi (A-L) [Dubrovnik's nobility, vol. 2: Noble kindreds (A-L)] (Zagreb; Dubrovnik: Zavod za povijesne znanosti HAZU u Dubrovniku, 2012), 91-92, 94; Vekarić, Vlastela grada Dubrovika, 5, 116.

${ }^{40}$ According to the 1817 census, as many as 7 noble palaces in the Ulica od puča were unihabited, while the mansion registered under number 384 actually encompassed two palaces: one at the address Ulica izmedu polača 13, and the other at Od puča 12. Both palaces were owned by the Pozza noble family, while the palace in the Ulica od puča the family inherited from Frano-Marija Damjanov Bobali. For more on this complex see: Lazarević, Vlasteoske kuća u gradu Dubrovniku 1817. godine, 113-115.
} 
to assume that in this city area too their number must have been far greater. ${ }^{41}$ This street, former Crevljarska, was the the backbone and trade centre of the city. Later, probably in the early fifteenth century when the communal houses were built, the "elite" part of the city shifted northwards, around the Placa. ${ }^{42}$ This process may be discerned from the analysis of the parician houses on the basis of the 1817 census, which in fact seals the state from around the fall of the Republic, but we don't have any other sources about the locations of the noble houses and palaces in this period. In 1817, the houses facing the Placa were occupied by as many as 57 members of the noble circle. ${ }^{43}$ This centre shift was accompanied by certain communal solutions, which might explain why the main city fountains, Great and Small Onofrio fountains, were positioned at the very ends of the main street. Life simply moved onto the Placa, with the loggia, market place, main guards, patron church, Petilovrijenci church, which was burnt down in the fire following the Great Earthquake of 1667, Customs House, Franciscan monastery, convent of St Clare, and generally, this "uličetina" (It. stradone, Stradun or Placa) became the central setting of urban life.

\section{Conclusion}

Although the Dubrovnik area is rich in fresh water resources, concern for the water supply dates, to our knowledge, since the late antiquity, as evidenced by the discovered wells at Bunićeva poljana, beneath the Cathedral, in the Ulica od puča and at some other sites in the walled inner city area. Also, collection of rainwater into cisterns (gustijerne) was another common method of water supply.

A growing city population in the 15th century became a serious challenge to the current water supply solutions, especially during dry summer seasons when the cisterns ran dry and the water in the wells turned brackish. In order to deal with this problem, Ragusan government decided to build an aqueduct, and for this project they engaged experts from Italy. Once the entire aqueduct route according to the design of Onofrio della Cava was completed, the construction of the fountains in the city nucleus commenced. The Great Onofrio Fountain was located at the

\footnotetext{
${ }^{41}$ Vekarić, Vlastela grada Dubrovnika, 1, 219; Lazarević, Vlasteoske kuće u gradu Dubrovniku 1817. godine, 15, 239-240.

${ }^{42}$ Danko Zelić, "Utilitas et lucrum - općinske kuće u srednjovjekovnom Dubrovniku” [Utilitas et lucrum: Communal houses in medieval Dubrovnik], in: Umjetnost i naručitelji: Zbornik Dana Cvita Fiskovića, ed. Jasenka Gudelj (Zagreb: Institut za povijest umjetnosti, Odsjek za povijest umjetnosti Filozofskog fakulteta Sveučilišta u Zagrebu, 2010), 9-24. For more details on moving the urban city space in medieval Dubrovnik northwards see: Irena Benyovsky Latin, "Dubrovnik's Burgus of St Blasius in the $13^{\text {th }}$ Century", in: Towns and Cities of the Croatian Middle Ages: Authority and Property, ed. Irena Benyovsky Latin and Zrinka Pešorda Vardić (Zagreb: Hrvatski institut za povijest, 2014), 295-327; Irena Benyovsky Latin, Stipe Ledić, “The Estate of the Volcassio Family in Medieval Dubrovnik", Dubrovnik Annals 18 (2014): 7-45.

${ }^{43}$ Lazarević, Vlasteoske kuće u gradu Dubrovniku 1817. godine, 57-80, 85-129.
} 
western end of the Placa, in front of the Franciscan monastery and the convent of St Clare, while the other, Small Fountain was located at the farthest, eastern end of the Placa. Besides these two, the city also had a Jewish Fountain, a fountain in the Rector's Palace, cisterns in the Franciscan and Dominican friaries, along with private cisterns located in private houses and patrician palaces. The conveyance of fresh water to the city contributed to the improvement of the living conditions, hygiene and quality of urban life in general, as well as economic growth.

These fountains became significant points in the urban space, meeting places, around which the city life thrived. The fact that the largest sexterium in the French census of 1808 and the census of 1817 was named after the Great Onofrio Fountain (Fontana Grande) is an eloquent testimony to their importance, even after the fall of the Republic.

The discovered wells from the late antiquity at Bunićeva poljana, in the proximity of the baptistry,which had stood on this site until the nineteenth century, Cathedral sanctuary, that is, entrance to the Cathedral prior to its reorientation in the Baroque period, speaks of the significance of this space. This must have also been the site of the house of Count Damjan Juda $(+1205)$, once the leading city figure, which further adds to this assumption. ${ }^{44}$ Before the construction of the aqueduct, the majority of wells was located in the Ulica od puča, after which this street was named. In the fifteenth century, when communal houses were built and when the Placa shaped into a well-organised urban area lined with shops and porticoes in the north-east part, this street became the main trade centre of the city, on the basis of which we might assume that the nobility increasingly grouped here. A new street regulation introduced a shift of the elite centre, by which the Placa became the main street. These changes were accompanied by new communal solutions, that is, the construction of the fountains at the either end of the thoroughfare.

${ }^{44}$ Lazarević, Vlasteoske kuće u gradu Dubrovniku 1817. godine, 188. 


\section{Archival sources}

Croatia - State Archives in Dubrovnik, fond 1. Reformationes

Croatia - State Archives in Dubrovnik, fond 2. Consilium Maius

Croatia - State Archives in Dubrovnik, fond 9. Diversa Notarie

Croatia - State Archives in Dubrovnik, fond 12.1. Testamenta Notariae

Croatia - State Archives in Dubrovnik, fond 15. Diversa Cancellariae

Croatia - State Archives in Dubrovnik, fond 47, Custodiae et armamentum

Croatia - State Archives in Dubrovnik, fond 460. Family Beritić

Croatia - State Archives in Split, fond 152, Arhiv mapa za Istru i Damlaciju (forth: AMID), kut. 145.

\section{Published sources and literature}

Andreis, Mladen; Benyovsky, Irena; Plosnić, Ana. "Socijalna topografija Trogira u 19. stoljeću" [Social topography of Trogir in the $19^{\text {th }}$ century]. Povijesni prilozi 25 (2003): 37-92.

Bettarini, Francesco. "I contratti di assunzione nella manifattura tessile Ragusea". Dubrovik Annals 20 (2016): 53-92.

Bettarini, Francesco. La comunità pratese di Ragusa (1414-1434). Crisi economicae migrazioni collettive nel Tardo Medioevo. Firenze: Olschki, 2012.

Bazala, Vladimir. Pregled povijesti zdravstvene kulture Dubrovačke Republike [An overview of healthcare in the Dubrovnik Republic]. Zagreb: Dubrovački horizonti, 1972.

Belamarić, Joško. Dioklecijanov akvedukt [Diocletian's aqueduct]. Split: Ministarstvo kulture Republike Hrvatske, Uprava za zaštitu kulturne baštine, Konzervatorski odjel, 1999.

Belamarić, Joško. "Urbanistički aspekti prve dubrovačke industrije u 15. stoljeću" [Urbanist aspects of Dubrovnik's earliest industry in the $15^{\text {th }}$ century]. In: Zbornik Dana Cvita Fiskovića II - Renesansa i renesanse u umjetnosti Hrvatske, eds. Predrag Marković and Jasenka Gudelj, 341-372. Zagreb: Institut za povijest umjetnosti, 2008.

Benyovsky Latin, Irena. "Dubrovnik's Burgus of St Blasius in the 13th Century". In: Towns and Cities of the Croatian Middle Ages: Authority and Property, eds. Irena Benyovsky Latin and Zrinka Pešorda Vardić, 295-327. Zagreb: Hrvatski institut za povijest, 2014.

Benyovsky Latin, Irena. Srednjovjekovni Trogir: prostor i društvo [Medieval Trogir: Space and society]. Zagreb: Hrvatski institut za povijest, 2009. 
Benyovsky Latin, Irena; Ledić, Stipe. "The Estate of the Volcassio Family in Medieval Dubrovnik". Dubrovnik Annals 18 (2014): 7-45.

Beritić, Lukša. "Dubrovački vodovod" [Dubrovnik's water supply system]. Anali Historijskog instituta JAZU u Dubrovniku 8-9 (1960-1961): 99-116.

Braudel, Fernand. Civilization and capitalism 15th - 18th century. Volume 1: The structures of everyday life. The limits of the possible. Translation from the French Revised by Sian Reynolds (London; Glasgow; Sydney; Auckland; Toronto; Johannesburg: William Collins Sons \& Co Ltd, 1981).

Bužančić, Radoslav. "Fontana Dioklecijanove carske palače" [The cistern in Diocletian's imperial palace]. Klesarstvo i graditeljstvo 1-2 (2009), no. 20: 54-65.

Crnković, Nikola. "Novaljska župna kronika o jedinstvenom vodoopskrbnom objektu na našem tlu" [The parish chronicle of Novalja on the unique water supply facilities in our country]. Croatica Christiana periodica 9 (1985), no. 15: 89-101.

Ćosić, Stjepan; Vekarić, Nenad. "Dubrovačka Republika" [The Dubrovnik Republic]. In: Hrvatska enciklopedija vol 3, 278-282. Zagreb: Leksikografski zavod Miroslav Krleža, 2001.

Diversis, Filip (de). Opis slavnoga grada Dubrovnika [A description of the glorious city of Dubrovnik], preface, transcription and translation from Latin Zdenka Janeković Römer. Zagreb: Dom i svijet, 2004.

Fisković, Cvito. "Petar Martinov iz Milana i pojava renesanse u Dubrovniku” [Pietro di Martino da Milano and the beginings of the Renaissance in Dubrovnik]. Prilozi povijesti umjetnosti u Dalmaciji 27 (1988): 89-144.

Grujić, Nada. "Knežev dvor u Dubrovniku prije 1435. godine" [The Rector's Palace in Dubrovnik before 1435]. Povijesni prilozi 40 (2005): 149-170.

Janeković Römer, Zdenka, "Extension of the Ragusan aqueduct from the spring in Knežica, 1518-1520: common concern of the government and people for the common good". In: Scripta in honorem Igor Fiskovic. Zbornik povodom sedamdesetog rodendana. Festschrift in the occasion of his 70th birthday, ed. Miljenko Jurković, Predrag Marković. Zagreb; Motovun: University of Zagreb, Faculty of Humanities and Social Sciences, International Research Center for Late Antiquity and the Middle Ages, 2015.

Jeremić, Risto; Tadić, Jorjo. Prilozi za istoriju zdravstvene kulture starog Dubrovnika [Contributions to the history of healthcare in historical Dubrovnik]. vol. I. Beograd: Biblioteka Centralnog higijenskog zavoda, 1938.

Jeremić, Risto; Tadić, Jorjo. Prilozi za istoriju zdravstvene kulture starog Dubrovnika [Contributions to the history of healthcare in historical Dubrovnik]. vol. III. Beograd: Biblioteka Centralnog higijenskog zavoda, 1940.

Kovačić, Ljiljana. "Antički vodovod - Vodovađa" [The ancient water supply system of Vodovađa]. Zbornik dubrovačkih muzeja (2004): 331-340. 
Lazarević, Ivana. "Granice dubrovačkih seksterija” [The boundaries of Dubrovnik's sestieri]. Anali Zavoda za povijesne znanosti HAZU u Dubrovniku 50 (2012): 63-74.

Lazarević, Ivana. Vlasteoske kuće u gradu Dubrovniku 1817. godine [Nobile houses in Dubrovnik in 1817]. Zagreb; Dubrovnik: Zavod za povijesne znanosti HAZU u Dubrovniku, 2014.

Lučić, Josip. Prošlost dubrovačke Astareje. Župe, Šumeta, Rijeke, Zatona, Gruža i okolice grada do 1366 [A history of Dubrovnik's Astarea: Župa, Šume, Rijeka, Zaton, Gruž, and the surroundings of the city before 1366]. Dubrovnik: Matica hrvatska, 1970.

Majer Jurišić, Krasanka; Šurina, Edita. Velika Onofrijeva fontana u Dubrovniku - povijesnoumjetnička i konzervatorska studija [Onofrio's large cistern in Dubrovnik: An art-historical and conservationist study]. Zagreb: Ministarstvo kulture, Uprava za zaštitu kulturne baštine, 2016.

Marasović, Katja; Perojević, Snježana; Margeta, Jure; Katić Miroslav; Bojanić, Davor. "Istraživanje salonitanskog akvedukta 2014.-2015." [Research on the Salonitan aqueduct (2014-2015)]. Vjesnik za arheologiju i povijest Dalmatinsku 109 (2016): 129-154.

Marasović, Katja; Margeta, Jure. "Istraživanje antičkih vodnih zahvata na izvoru rijeke Jadro/A study of Roman water intake structures at the Jadro River's spring". Vjesnik za arheologiju i historiju dalmatinsku 110 (2017), no. 2: 509-532.

Marić, Mara. Projektno tehnička dokumentacija za obnovu trase dubrovačkog renesansnog vodovoda. Konzervatorski elaborat (predstudija obnove i potrebna ispitivanja) [Project documentation for the renovation of Dubrovnik's historical water supply system: A preliminary conservationist study]. Dubrovnik: Trames Consultants d.o.o., 2015.

Miović, Vesna. Židovski geto u Dubrovačkoj Republici (1546-1808) [The Jewish ghetto in the Dubrovnik Republic (1546-1808)]. Zagreb; Dubrovnik: Hrvatska akademija znanosti i umjetnosti, Zavod za povijesne znanosti u Dubrovniku, 2005.

Mumford, Lewis. Grad u historiji. Njegov postanak, njegovo mijenjanje, njegovi izgledi [The City in History: Its Origins, Its Transformations, and Its Prospects]. Zagreb: Naprijed, 1988.

Ničetić, Antun. Nove spoznaje o postanku Dubrovnika, o njegovu brodarstvu i plovidbi svetog Pavla [New insights about the emergence of Dubrovnik, its shipping, and the navigation of St Paul]. Dubrovnik: Sveučilište u Dubrovniku, 2005.

Ničetić, Antun. Povijest dubrovačke luke [A history of Dubrovnik's harbour]. Dubrovnik: Zavod za povijesne znanosti HAZU u Dubrovniku, 1996. 
Novak Klemenčič, Renata. "Dubrovniška Velika fontana" [Dubrovnik’s Large Cistern]. Zbornik za umetnosno zgodovino, new series 39 (2003): 57-91.

Roller, Dragan. "Dubrovački zanati u XV. i XVI. stoljeću" [Crafts in Dubrovnik (15th-16th c.)]. In: Građa za gospodarsku povijest Hrvatske, vol. 2, ed. Mijo Mirković. Zagreb: Jugoslavenska akademija znanosti i umjetnosti, 1951.

Sarti, Raffaella. Živjeti u kući: stanovanje, prehrana i odijevanje u novovjekovnoj Europi (1500.-1800.) [Living in a house: Housing, food, and clothing in early modern Europe]. Zagreb: Ibis grafika, 2006.

Seferović, Relja; Stojan, Mara. "Čudo vode: prolegomena za ranorenesansni vodovod u Dubrovniku" [The miracle of water: Prolegomena to the Renaissance water supply system in Dubrovnik]. Anali Zavoda za povijesne znanosti HAZU u Dubrovniku 44 (2006): 95-137.

Stojan, Slavica. Vjerenice i nevjernice. Žene u svakodnevici Dubrovnika (16001815) [Brides and adulteresses: Women in the everyday life of Dubrovnik (16001815)]. Zagreb; Dubrovnik: Zavod za povijesne znanosti HAZU u Dubrovniku, 2003.

Stošić, Josip. "Prikaz nalaza ispod katedrale i Bunićeve poljane u Dubrovniku" [Presentation of the finds under the cathedral and Bunićeva Poljana in Dubrovnik]. Arheološka istraživanja u Dubrovniku i dubrovačkom području 12 (1988): 15-38.

Suić, Mate. Antički grad na istočnom Jadranu [Ancient cities in the Eastern Adriatic]. Zagreb: Golden marketing, 2003.

Vekarić, Nenad. Nevidljive pukotine. Dubrovački vlasteoski klanovi [Invisible fissures: Ragusan patrician clans]. Zagreb; Dubrovnik: Zavod za povijesne znanosti HAZU u Dubrovniku, 2009.

Vekarić, Nenad. Vlastela grada Dubrovnika, vol. 1 - Korijeni, struktura i razvoj dubrovačkog plemstva. [Dubrovnik's nobility, vol. 1: The roots, structure, and development of Dubrovnik's nobility]. Zagreb; Dubrovnik: Zavod za povijesne znanosti HAZU u Dubrovniku, 2011.

Vekarić, Nenad. Vlastela grada Dubrovnika, vol. 2. Vlasteoski rodovi (A-L) [Dubrovnik's nobility, vol. 2: Noble kindreds (A-L)]. Zagreb; Dubrovnik: Zavod za povijesne znanosti HAZU u Dubrovniku, 2012.

Vekarić, Nenad. Vlastela grada Dubrovnika, vol. 5 - Odabrane biografije (E - Pe) [Dubrovnik's nobility, vol. 5: Selected biographies (E-Pe)]. Zagreb; Dubrovnik: Zavod za povijesne znanosti HAZU u Dubrovniku, 2014.

Vekarić, Nenad. Vlastela grada Dubrovnika, vol. 8. Genalogije (M-Z) [Dubrovnik's nobility, vol. 8: Geenealogies (M-Z)]. Zagreb; Dubrovnik: Zavod za povijesne znanosti HAZU u Dubrovniku, 2017. 
Zelić, Danko. "Arhitektura starih katedrala". In: Katedrala Gospe Velike u Dubrovniku, ed. Katarina Horvat Levaj. Dubrovnik; Zagreb: Gradska župa Gospe Velike and Institut za povijest umjetnosti, 2014.

Zelić, Danko. "Utilitas et lucrum - općinske kuće u srednjovjekovnom Dubrovniku" [Utilitas et lucrum: Communal houses in medieval Dubrovnik]. In: Umjetnost i naručitelji: Zbornik Dana Cvita Fiskovića, ed. Jasenka Gudelj, 9-24. Zagreb: Institut za povijest umjetnosti, Odsjek za povijest umjetnosti Filozofskog fakulteta Sveučilišta u Zagrebu, 2010.

\footnotetext{
* Irena Ipšić, Studij Povijest Jadrana i Mediterana, Sveučilište u Dubrovniku, Branitelja Dubrovnika 41, 20000 Dubrovnik, Republika Hrvatska, E-mail adresa: irenaipsic@gmail.com

** Ivana Lazarević, Zavod za povijesne znanosti HAZU u Dubrovniku, Lapadska obala 6, 20000 Dubrovnik, Republika Hrvatska, E-mail adresa: ivana.lazarevic@du.t-com.hr
} 
Irena Ipšić
Ivana Lazarević

\section{Voda u urbanom prostoru Dubrovnika}

\section{Sažetak}

Dubrovačko područje je bogato vodom i izvorima, ali usprkos tomu briga o vodoopskrbi stanovništva grada datira, koliko znamo, još od kasne antike. Tome svjedoče pronađeni bunari na Bunićevoj poljani, ispod katedrale, u Ulici Od puča i na još nekim mjestima u gradu unutar zidina. Također, stanovništvo se vodom opskrbljivalo i sabiranjem kišnice u cisterne (gustijerne). Rastom broja stanovništva i opskrba vodom je postala upitna pogotovo za vrijeme ljetnih suša kada su cisterne presušivale, a voda u bunarima postajala preslana. Da bi riješila problem, dubrovačka vlada se odlučila graditi vodovodni sustav za čiju su izgradnju doveli stručnjake iz Italije. Nakon dovršetka izgradnje cijelog vodovodnog kanala po projektu Napolitanca Onofrija della Cave, počelo se s gradnjom fontani u samoj gradskoj jezgri. Jedna, Velika Onofrijeva smještena je na zapadnom kraju Place, ispred franjevačkog samostana i samostana klarisa, a druga i manja na istočnom kraju Place. Pored njih, u Gradu su se nalazile i židovska fontana, fontana u Kneževom dvoru, cisterne u franjevačkom i dominikanskom samostanu, ali i privatne cisterne u privatnim kućama i vlasteoskim palačama. Dovođenjem tekuće vode u grad poboljšala se kvaliteta života i higijenski uvjet, a time je omogućen i razvoj gospodarstva.

Ove fontane su postali važni punktovi, sastajališta, mjesta oko kojih se odvijao život grada. O njihovoj važnosti svjedoči i činjenica da je najveći seksterij u francuskom popisu iz 1808. i u popisu stanovništva 1817. nazvan upravo po Velikoj Onofrijevoj fontani (Fontana Grande).

Pronađeni pučevi na Bunićevoj poljani, u blizini krstionice, koja se nalazila na ovom trgu do 19. stoljeća, svetišta katedrale, odnosno ulaza u katedralu prije njezine preorijentacije u baroku, govori o važnosti ovog prostora. Tu je vjerojatno bila i kuća kneza Damjana Jude (+1205), nekadašnjeg prvog čovjeka grada što dodatno potkrepljuje ovu tvrdnju. Prije izgradnje vodovoda, najveći broj pučeva nalazilo se u Ulici Od puča po kojima je ulica i dobila ime, a godine 1817. u toj ulici živi čak 30 članova vlasteoskog kruga. U 15. stoljeću kad su izgrađene općinske kuće i kad je Placa postala uređeni dio grada s trgovinama i trijemovima na sjeveroistočnom dijelu, ova ulica je postala glavno trgovačko središte grada i možemo samo pretpostaviti da je tu živjelo puno vlastele. Nakon nove regulacije ulica, došlo je do pomicanja elitnog središta i glavna ulica je postala Placa. Ove promjene je pratilo i rješavanje komunalnih pitanja, odnosno izgradnja fontani na krajevima ove najvažnije ulice.

Ključne riječi: Dubrovnik, voda, Onofrio della Cava, vodovod, zdenci, cisterne 